\title{
Multidimensional Comparative Analysis as a Tool of Spatial Order Evaluation: A Case Study from Southwestern Poland
}

\author{
Malwina Mikołajczyk*, Beata Raszka \\ The Faculty of Environmental Engineering and Geodesy, Wrocław University of Environmental \\ and Life Sciences, Wrocław, Poland
}

Received: 14 February 2018

Accepted: 3 June 2018

\begin{abstract}
The quality of land development has an impact on quality of life. For better state of inhabitants the land management process should contribute to social and economic development, taking care of the environment and tradition of a place. Consequently, in such well-developed places we will find spatial order. This multidimensional phenomenon is described by the polish law in the Spatial Planning and Land Development Act of 27 March 2003. Spatial order includes the environmental, socio-economic, cultural, functional and aesthetic aspects of some areas. This article presents a new methodological approach to the assessment of spatial order at the local level. As a method, we propose the multidimensional comparative analysis. This method allows for calculating the value of spatial order composite index, creating the ranking of communities, choosing the benchmark units and comparing the studied objects. The research area includes 110 urban and rural communities of southwestern Poland. The state of spatial order for 2009 and 2013 was studied. The obtained results show differentiation of the level of spatial order and disproportions between the rural and urban communities.
\end{abstract}

Keywords: spatial order, spatial development, composite index, multidimensional index

\section{Introduction}

Spatial order is formally next to sustainable development as the basis of activities associated with the formation of spatial policy by the local government units and the government administration bodies in

*e-mail: malwina.mikolajczyk@outlook.com
Poland, intended use of areas for specific purposes as well as establishing the principles of their management and development. Spatial order has been introduced in article 1 paragraph 1 of the Spatial Planning and Land Development Act of 27 March 2003 (Journal of Laws 2003 No. 80 item 717). This act defines the spatial order concept as a kind of formation of the area, which creates a harmonious whole and includes in the structured relationships all the conditions and requirements: socio-economic, 
environmental, functional, cultural, aesthetic and compositional $^{1}$.

Spatial order, in spite of its legal definition, is not clear enough as a concept and is not connected with one particular phenomenon. It is multifaceted [1-5] and, in Polish literature, is related to several characteristics such as: the aesthetic of a place, its architecture, functionality, culture, environment, society and economy. Also, the connection of spatial order to sustainable development $[6,7]$ and to the integrated order [8] can be found in Polish literature. Sustainable development integrates social, environmental, and economic sustainability [9]. The integrated order is understood as a positive final state of sustainable development $[10,11]$ - and in a similar way spatial order can be considered. In this article spatial order refers to the level of community (local level) and it is understood as:

- The state of the community at a particular time.

- A multidimensional phenomenon that includes environmental, socio-economic, functional, cultural and aesthetic aspects.

In Polish academic literature, among the researchers of spatial order there is consensus of the complexity and multidimensionality of this phenomenon [1-5]. Although spatial order was quite often described as the aesthetic of the place, such an approach was criticized as too narrow. So far there is no consensus on a set of aspects that would be final and unchanging.

Szmidt [1] broadly discussed the concept of spatial order and listed four aspects: natural, conventional, pragmatic and constructional. The natural order is primal and common as well as dynamic and unstable. Spatial management, according to the natural aspect, can be expressed in two ways: in adaptation or in opposition to nature. The next aspect - conventional - is what "there should be" and it comes directly from humans. This aspect is the result of individual preferences. The pragmatic aspect is associated with the style of the era and it contains the culture content: traditions, experience, ability to meet aspirations. The last one - constructional aspect - is related to architecture, the economy of buildings, the correctness of the construction, as well as its adaptation to human needs. The author claims that spatial order is a multidimensional phenomenon.

More than 20 years later, researchers listed different sides of spatial order. Gorzelak [2] mentioned two aspects that overlapped: aesthetic and functional, while others treat the aesthetics of the place only as a value added to the rationally and functionally developed space. Spatial order strives to achieve the desired spatial development, although it seems that the compositional and aesthetic aspect is not the main element, but ordered relations of conditions and socioeconomic requirements $[12,13]$. The aesthetic may

Art. 2, point 1 of Spatial Planning and Land Development Act of 27 March 2003 (Journal of Laws 2003 No. 80 item 717) not be the most important characteristic of a place but it is significant. Mierzejewska [3] listed six aspects of spatial order, namely: functional, economic, ecological, political, cultural and aesthetic, and Polski [14] only three: ecological, social and economic. A slightly different, but also multidimensional division of spatial order, was made by the sociologists Jałowiecki and Szczepański [15]. In the urban space they distinguished the following aspects: urban and architectural, functional, aesthetic, psychosocial and ecological. It is assumed that spatial order is a form of public good, and all the inhabitants of a territorial unit should participate in its development. The main factors of spatial order preservation are: suitable spatial arrangement of various functions (optimal selection of functions to the conditions of the area) as well as conflict-free and beneficial neighborhood functions [16]. Spatial order is a desirable state of development, a state that is compatible with the principles of sustainable development [17], and obtaining spatial order can be regarded as a fundamental objective of spatial planning. The opposite of the spatial order is spatial entropy (disorder, chaos), which finds its reflection in the degraded landscape [18].

Spatial order can be considered at different levels - from the global one to the plot [19]. The concept of sustainable community is close to the concept of spatial order. According to Roseland [20], such communities should be cleaner, healthier, economical, self-sufficient, and they should possess the ensured energy sources, food and other resources.

The purpose of this analysis was to develop a methodology including calculation of spatial order composite index and evaluation spatial order of the urban and rural communities of southwestern Poland.

\section{Material and Methods}

In these studies the selection of features was a compromise between the assumptions of the study and data availability. Not all the necessary data was accessible for the community level or for each studied community, or there were data gaps for one of the two studied periods. As the source of data the Local Data Bank was selected because of equal availability of data for all of the communities. For the cultural as well as for the aesthetic aspect the available data was not satisfactory. For the cultural aspect data was related to a readership and the libraries, and this range is insufficient. For the aesthetic aspect the Local Data Bank does not collect any data, and this was the reason for exclusion of this aspect from the study.

One hundred and ten communities of southwestern Poland were analyzed: 32 rural $(29 \%$ of the analyzed municipalities) and 78 urban (71\%). The area is shown in Fig. 1. The studies were conducted for 2009 and 2013 and they included four out of five aspects of spatial order. Each aspect is characterized by intentionally chosen features - variables included in Table 1. 

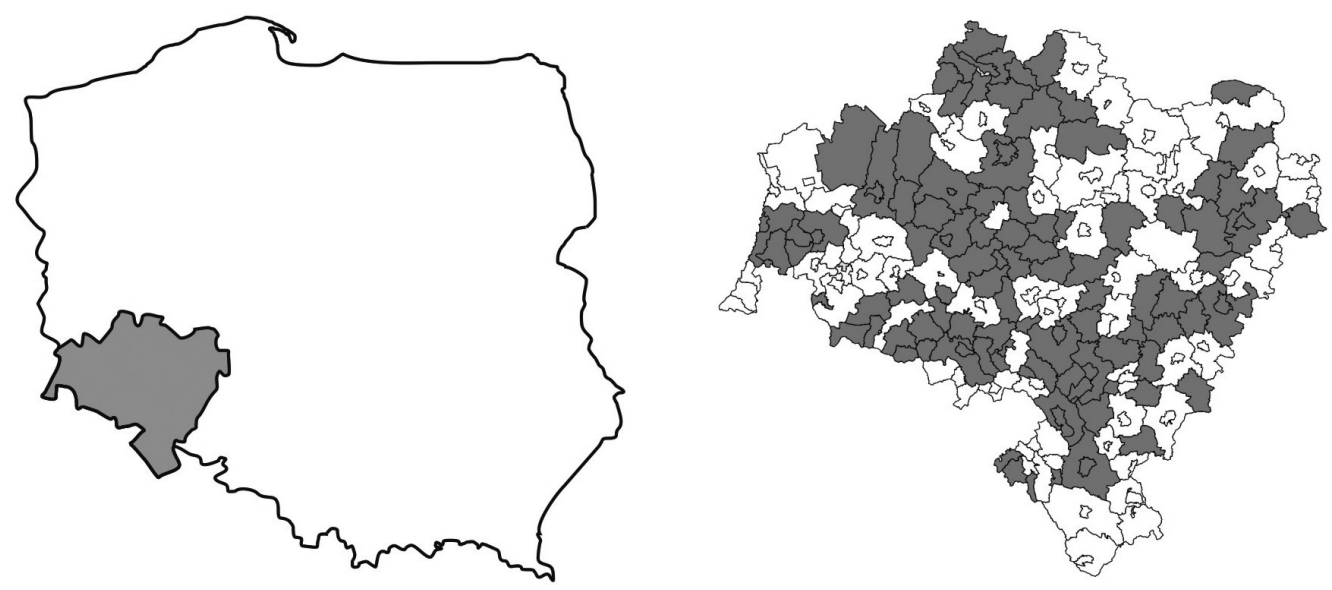

Fig.1. On the left side - Lower Silesia on the Polish map and on the right side - the research area of the Lower-Silesian communities marked in dark colour; communities marked in white are excluded from analysis.

\section{Research Procedures}

It was important to reject all the redundant data from the preselected variables. For this purpose the statistical procedures including study of variability of characteristics in relation to the objects and study of the degree of correlation of included data were used. The coefficient of variation was used to examine the variability of features [21]:

$$
V=\frac{s}{\mu}
$$

where:

$s$ - standard deviation

$\mu$ - arithmetic average

The low diversity of a variable means that it has low information value and thus it should be rejected. A critical value of $10 \%$ was assumed. The degree of variables correlation was determined using Spearman's coefficient of rank correlation [22]. This coefficient is often more powerful in the context of abnormality [23].

$$
r_{s}=1-\frac{6 \cdot \sum d_{i}^{2}}{n\left(n^{2}-1\right)}
$$

...where:

$\mathrm{d}_{\mathrm{i}}$ - the difference between the ranks $\mathrm{X}$ and $\mathrm{Y}$ : Rxi-RYi $\mathrm{n}$ - number of observations

After these procedures, 11 variables were rejected because the data overlapped. The other variables became subjected to the process of standardization, where the quotient transformation formula was used [24, 25]:

$$
z_{i j}=\frac{x_{i j}}{S}
$$

...where:

$\mathrm{x}_{\mathrm{ij}}$ - value of the $\mathrm{j}$-th variable for the $\mathrm{i}$-th object;

$\mathrm{s}$ - standard deviation

Based on the previously transformed variables, the composite index was calculated by applying the Perkal formula [26]:

$$
W_{s}=\frac{\sum y_{i j}}{p}
$$

...where:

$W_{s}$ - composite index

$y_{i j}$ - standardized value of the $\mathrm{j}$-th variable for the i-th object

$p$ - number of variables

The multidimensional index of spatial order was composed from four sub-indexes of environmental, socio-economic, functional and cultural data. The values of the composite index were calculated for spatial order as a whole and for each aspect separately. The higher the value of the index, the better the ranking of community. Obtained values were classified into three categories indicating low, medium and high levels of the studied phenomenon. The community with the highest results may be considered as a model.

\section{Results and Discussion}

\section{The Evaluation of the Environmental Aspect}

Each community was evaluated using the composite index of environmental aspect of spatial order and the ranking of communities for 2009 and 2013 was received. The values of the indicator for 2009 ranged from 0.35 to 2.30 with an average of 1.02 . The communities with high, medium and low levels of spatial order were distinguished by dividing the composite index values into three equal classes: $2.30-1.65 ; 1.65-0.99$; and 
Table 1. Analyzed variables of spatial order (*landscape parks, ecological lands and landscape-nature protected complexes; **national parks and nature reserves [45]).

\begin{tabular}{|c|c|}
\hline Aspect of spatial order & Variable \\
\hline \multirow{7}{*}{ Environmental } & Share of the protected areas in the total area of the community \\
\hline & Share of the „soft” protected areas in the total area of the community * \\
\hline & Share of the „hard" protected areas in the total area of the community ** \\
\hline & Share of the green areas in the total area of the community \\
\hline & Forestation rate \\
\hline & Share of the population using the sewage system in the general population number \\
\hline & Total amount of municipal waste per capita \\
\hline \multirow{10}{*}{ Socio-economic } & Net internal migration per 1,000 population \\
\hline & Birthrate \\
\hline & Average usable floorspace for one person \\
\hline & Average number of people per apartment \\
\hline & Children aged 3-5 per one place in nursery school \\
\hline & Clinics per 10,000 population \\
\hline & Pharmacy per 10,000 population \\
\hline & Share of registered unemployed in the total working age population \\
\hline & Business entities registered in the REGON system per 10,000 population \\
\hline & Business entities deregistered from out the REGON system per 10,000 population \\
\hline \multirow{5}{*}{ Functional } & Share of local development plans in the total municipal area \\
\hline & Density of the gas network \\
\hline & Density of the water supply network \\
\hline & Share of the population using the gas network \\
\hline & Share of the population using the water supply network \\
\hline \multirow{5}{*}{ Cultural } & Number of library readers per 1,000 population \\
\hline & Number of loans per one reader \\
\hline & Houses, cultural centres, clubs per 10,000 population \\
\hline & Libraries and branches per 10,000 population \\
\hline & Country clubs per 10,000 population \\
\hline
\end{tabular}

0.99-0.35. The situation in 2013 presented differently, the obtained values ranging from 0.69 to 2.45 , and the average was 1.30 . The composite index values were divided into three classes: 2.45-1.86; 1.86-1.27; and 1.27-0.69. The results are included in Table 2 and Fig. 2.

In 2009 and 2013 the urban communities were rated higher than the rural ones. The development of the sewage network carried out in Poland in 2002-2012 [27] had a significant impact on the increase of the value of this indicator. In communities located around larger cities, the index values were lower. In the case of Lower Silesia, since the 1990s changes in functional-spatial structure have been observed around large cities that have their direct environmental effects [28]. Almost all of the highest evaluated communities in 2009 and 2013 had protected areas on their territory, with the exception of the urban community of Chojnów. This community did not have protected areas at all but in 2009 was ranked eighth, and in 2013 eleventh. Chojnów was characterized by the highest share of green areas.

\section{Evaluating the Socio-Economic Aspect}

The values of the composite index for the studied communities in 2009 ranged from 2.25 to 4.97 and the average was 3.53. Five out of the twelve best ranged communities were urban (Karpacz, Polanica-Zdrój, Szklarska Poręba, Szczawno-Zdrój ans ŚwieradówZdrój), and seven were rural (Kobierzyce, Czernica, 
Table 2. Evaluation of the environmental aspect of spatial order in 2009 and 2013.

\begin{tabular}{|c|c|c|c|c|}
\hline \multirow{2}{*}{ Level } & \multicolumn{4}{|c|}{ The environmental aspect of spatial order } \\
\cline { 2 - 6 } & Number of communities & $\%$ & Number of communities & $\%$ \\
\hline High & 8 & 7.3 & 13 & 11.8 \\
\hline Medium & 32 & 29.1 & 31 & 28.2 \\
\hline Low & 70 & 63.6 & 66 & 60 \\
\hline
\end{tabular}

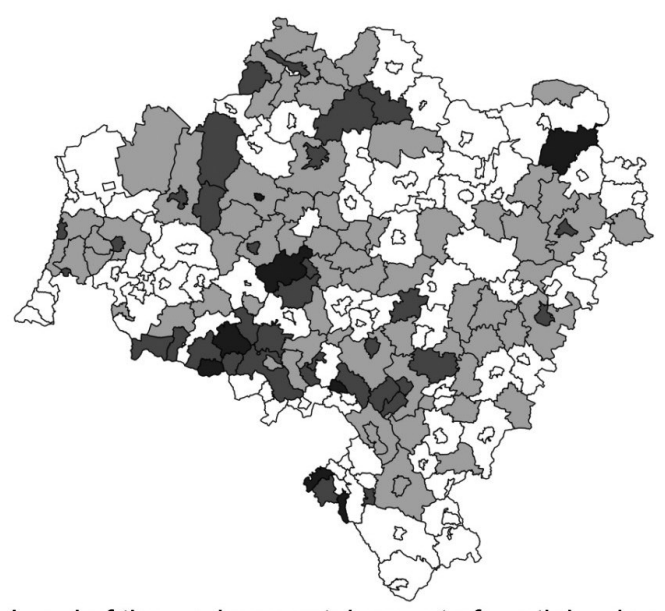

Level of the environmental aspect of spatial order in 2009

$$
\begin{gathered}
\text { low } \\
\text { medium } \\
\text { high }
\end{gathered}
$$

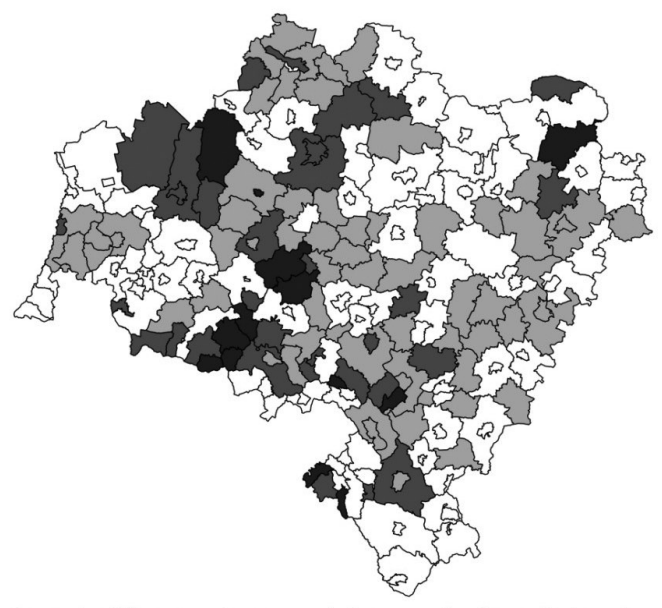

Level of the environmental aspect of spatial order in 2013

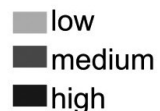

Fig. 2. Level of environmental aspect of spatial order in Lower-Silesian communities in 2009 and 2013.

Żórawina, Lubin, Długołęka, Jerzmanowa and Wisznia Mała). Among the communities rated average, 26 were urban and 53 were rural, only one from the 19 lowestrated communities was urban (Piława Górna). In 2013 the values of the composite index of the socio-economic aspect ranged from 2.05 to 4.21 , the average was 2.83 . The average for urban communities was 2.99, and for rural 2.77. The results are included in Table 3. Four out of six of the highest-rated objects were rural communities (Kobierzyce, Długołęka, Czernica and Miękinia) and only two were urban (Karpacz and Polanica-Zdrój). The values of the composite index of the socio-economic aspect obtained in 2013 were lower than in 2009. In 2009 the majority of communities were rated average, whereas in 2013 more than half received the lowest rating. Moreover, in 2009 twelve communities were rated highest, while in 2013 only six (Fig. 3).

In studies of southwestern Polish communities conducted separately for social and economic aspects in 2000-2010, the authors showed a decrease in the value of the composite index of social aspect [29], and for the economic one a slow increase [30].

Table 3. Evaluation of the socio-economic aspect of spatial order in 2009 and 2013.

\begin{tabular}{|c|c|c|c|c|}
\hline \multirow{2}{*}{ Level } & \multicolumn{4}{|c|}{ The socio-economic aspect of spatial order } \\
\cline { 2 - 6 } & Number of communities & $\%$ & Number of communities & $\%$ \\
\hline High & 12 & 10.9 & 6 & 5.5 \\
\hline Medium & 79 & 71.8 & 48 & 43.6 \\
\hline Low & 19 & 17.3 & 56 & 50.9 \\
\hline
\end{tabular}




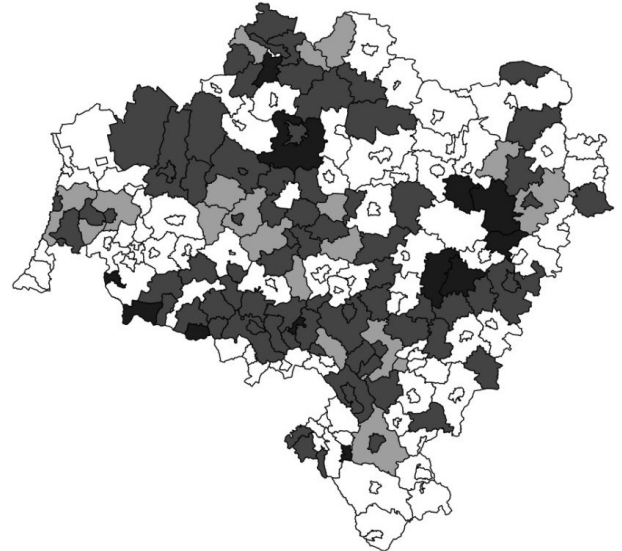

Level of the socio-economic aspect of spatial order in 2009

low

medium

Wigh

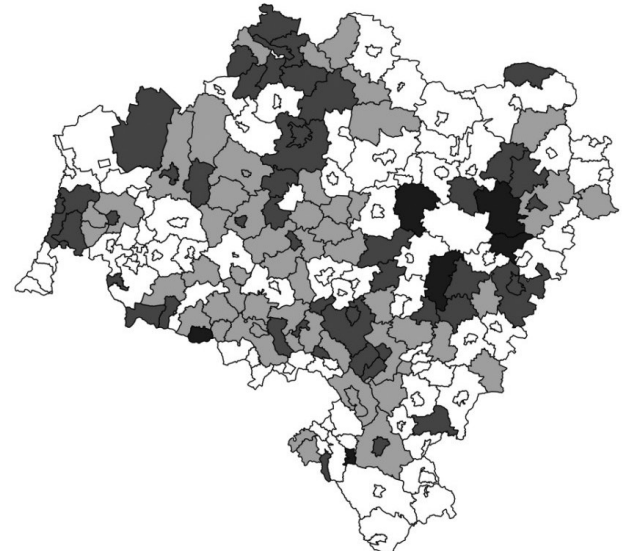

Level of the socio-economic aspect of spatial order in 2013

low
medium
high

Fig. 3. Level of socio-economic aspect of spatial order in Lower-Silesian communities in 2009 and 2013.

Evaluating the Functional Aspect

The values obtained in 2009 ranged from 0.62 to 3.90. The average were 2.13. The rural communities received lower rating, the average was 1.80 while for the urban ones it was 2.90. Almost all of the urban communities were in the best-rated class. For 2013 the obtained values ranged from 0.94 to 4.20 and the average was 2.46. Fig. 4 and Table 4 show the state in 2009 and 2013, and it can be noticed that during five years not much has changed. The average for the urban communities was 3.26, and for rural 2.14.

The infrastructure of the rural communities was less developed; in 2009 and 2013 the situation of the functional aspect of the rural communities looked similar. The development of the infrastructure of southwestern Poland in 2007-2013 was unsatisfactory [31]. The condition of the technical infrastructure of the village is one of the most serious barriers to development of rural communities [32].

\section{Evaluating the Cultural Aspect}

For 2009 the values of cultural aspect ranged from 0.69 to 3.30. The average was 1.53 . For 2013 the obtained values ranged from 0.94 to 2.97 and the average was 1.52. The results are shown in Fig. 5 and Table 5. The rural communities were rated higher in 2009 and 2013.

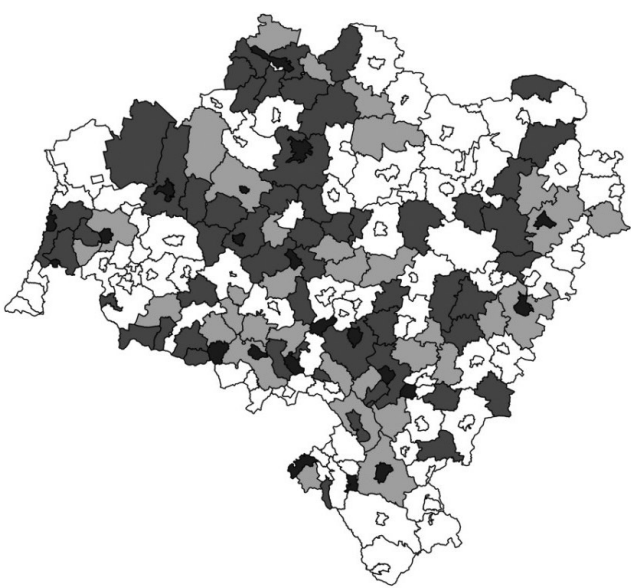

Level of the functional aspect of spatial order in 2009

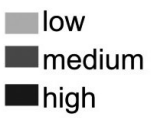

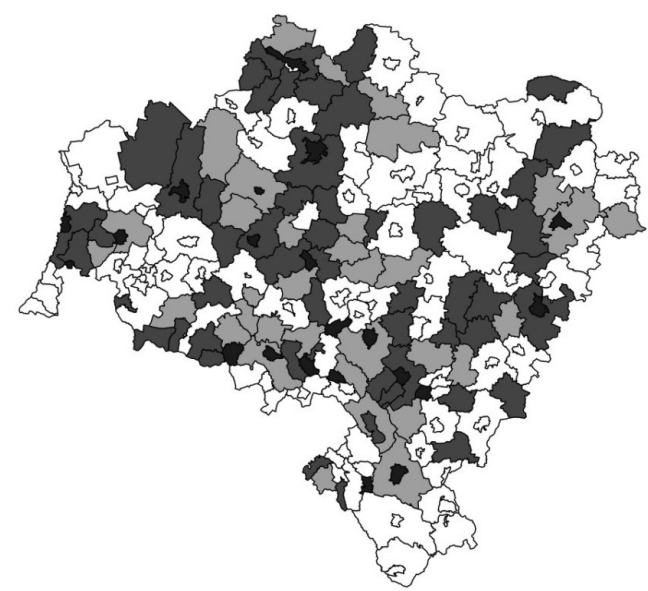

Level of the functional aspect of spatial order in 2013

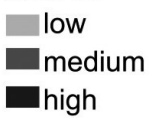

Fig. 4. Functional aspect of spatial order in Lower-Silesian communities in 2009 and 2013. 
Table 4. Evaluation of the functional aspect of spatial order.

\begin{tabular}{|c|c|c|c|c|}
\hline \multicolumn{5}{|c|}{ The functional aspect of spatial order } \\
\hline \multirow{2}{*}{ Level } & \multicolumn{2}{|c|}{2009} & \multicolumn{2}{|c|}{2013} \\
\hline & Number of communities & $\%$ & Number of communities & $\%$ \\
\hline High & 21 & 19.1 & 21 & 19.1 \\
\hline Medium & 55 & 50 & 54 & 49.1 \\
\hline Low & 34 & 30.9 & 35 & 31.8 \\
\hline
\end{tabular}

\section{Evaluating Spatial Order}

While calculating the composite index of spatial order, all of the variables were taken into account. For 2009 the obtained values ranged from 1.33 to 3.23 . The average was 2.20. Twenty-three (27\%) communities were rated highest: eight are rural (Lubin, Kobierzyce, Paszowice, Czernica, Jerzmanowa, Krośnice, Mietków and Żórawina), and the rest (15) were urban (Karpacz, Polanica-Zdrój, Bolesławiec, SzczawnoZdrój, Zgorzelec, Chojnów, Jedlina-Zdrój, Świdnica,

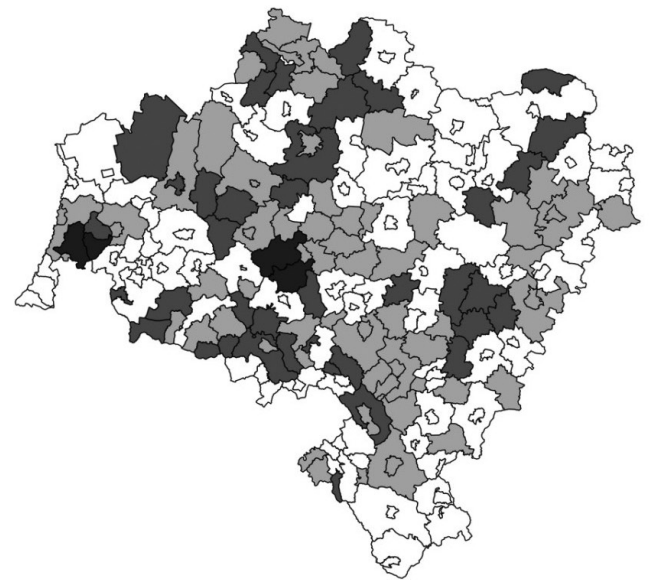

Level of the cultural aspect of spatial order in 2009

$$
\begin{aligned}
& \text { low } \\
& \text { medium } \\
& \square \text { high }
\end{aligned}
$$

Świeradów-Zdrój, Kowary, Oleśnica, Głogów, Szklarska Poręba, Duszniki-Zdrój and Złotoryja). Sixty-nine (62\%) communities were rated average: 52 were rural and 17 urban. Eighteen (11\%) communities - all rural - were rated lowest. The highest rated urban communities received high values for the functional, environmental and socio-economic aspects and low values for the cultural; the rural ones received high values for the socio-economic, cultural and environmental aspects, but low ones for the functional aspect.

For 2013 the obtained values ranged from 1.65 to 3.10. The average was 2.11. The results were different

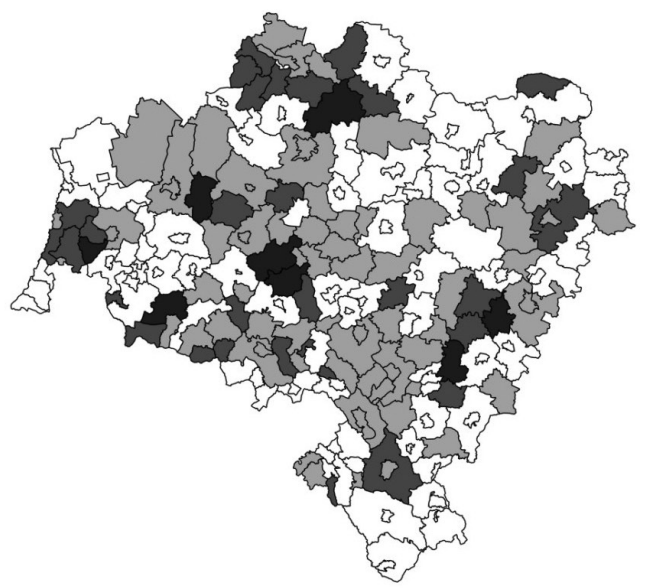

Level of the cultural aspect of spatial order

in 2013

$$
\begin{aligned}
& \text { low } \\
& \text { medium } \\
& \square \text { high }
\end{aligned}
$$

Fig. 5. Level of cultural aspect of spatial order in Lower-Silesian communities in 2009 and 2013.

Table 5. Evaluation of the cultural aspect of spatial order.

\begin{tabular}{|c|c|c|c|c|}
\hline \multirow{2}{*}{ Level } & \multicolumn{2}{|c|}{ The cultural aspect of spatial order } \\
\cline { 2 - 6 } & Number of communities & $\%$ & Number of communities & $\%$ \\
\hline High & 4 & 3.6 & 8 & 30 \\
\hline Medium & 39 & 35.5 & 72 & 27.2 \\
\hline Low & 67 & 60.9 & 65.5 \\
\hline
\end{tabular}




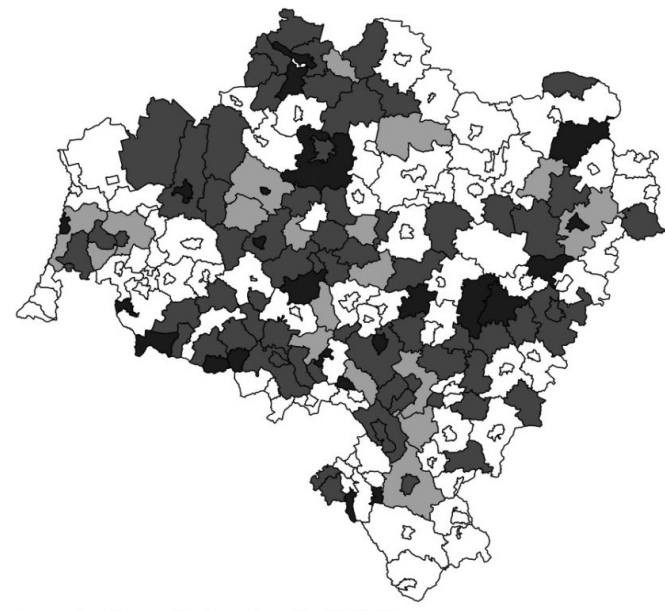

Level of spatial order in 2009

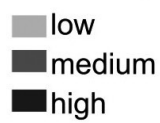

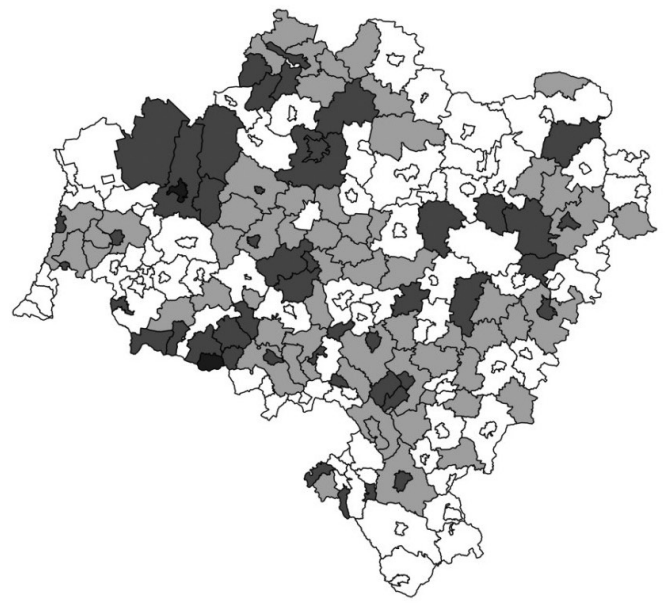

Level of spatial order in 2013

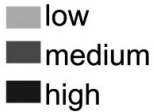

Fig. 6. Level of spatial order in Lower-Silesian communities in 2009 and 2013.

Table 6. Evaluation of spatial order.

\begin{tabular}{|c|c|c|c|c|}
\hline \multirow{2}{*}{ Level } & \multicolumn{2}{|c|}{ Spatial order } & \multicolumn{2}{c|}{2013} \\
\cline { 2 - 6 } & Number of communities & $\%$ & Number of communities & 1.8 \\
\hline High & 23 & 27 & 2 & 45 \\
\hline Medium & 69 & 62 & 63 & 50.5 \\
\hline Low & 18 & 11 & & 57.7 \\
\hline
\end{tabular}

than in 2009. Only two $(1,8 \%)$ communities were rated highest, both were urban (Karpacz and Bolesławiec), $45(40,5 \%)$ average, from which 20 were rural and the rest urban. Sixty-three $(57,7 \%)$ communities were rated lowest, of which five were urban. Between 2009 and 2013 the values of the composite index of spatial order of the Lower Silesia communities decreased. Fig. 6 and Table 6 show the results. For 2013 the majority of the communities rated highest in 2009 decreased its composite index value. In 201358 communities took a higher position than in 2009, and 50 a lower position. Only Karpacz received higher value in 2013, which can be noticed from the chart (Fig. 7).

\section{Discussion}

In these studies it was important to evaluate a complex phenomenon as a whole, simultaneously to evaluate a large number of objects (communities) in terms of this phenomenon so that all the objects could be compared. The multidimensional comparative analysis turned out to be the most suitable method recommended in literature [33-40]. It is well-suited to analyze a complex phenomenon like development [33], particularly because it is a tool for providing aggregate information [34]. Used as an instrument to assess societies [35] and to make comparisons of objects in terms of intentionally chosen features [36]. By replacing a set of many variables with one composite index we reduce the number of variables, facilitate estimation, and, in some cases, eliminate the possibility of obtaining incorrect values [37]. Well-chosen subindicators are combined to calculate a single index composite indicator, which has been widely accepted as a useful tool for benchmarking [38] in a variety of domains such as industrial competitiveness, sustainable development, globalisation and innovation [39, 40]. Multi-criteria spatial analysis might be used in the development of regional environmental policies [41]. Some authors have suggested that the use of a composite index can be controversial and can lead to questionable choices made by media or stakeholders [42] or to "mechanization" of the planning process [16].

The literature does not provide a specific number of subindicators (variables), which should be used to assess a complex phenomenon. In Polish literature some authors suggest using a set of 10-20 measurable indicators for each aspect [43], less than 30, or more 


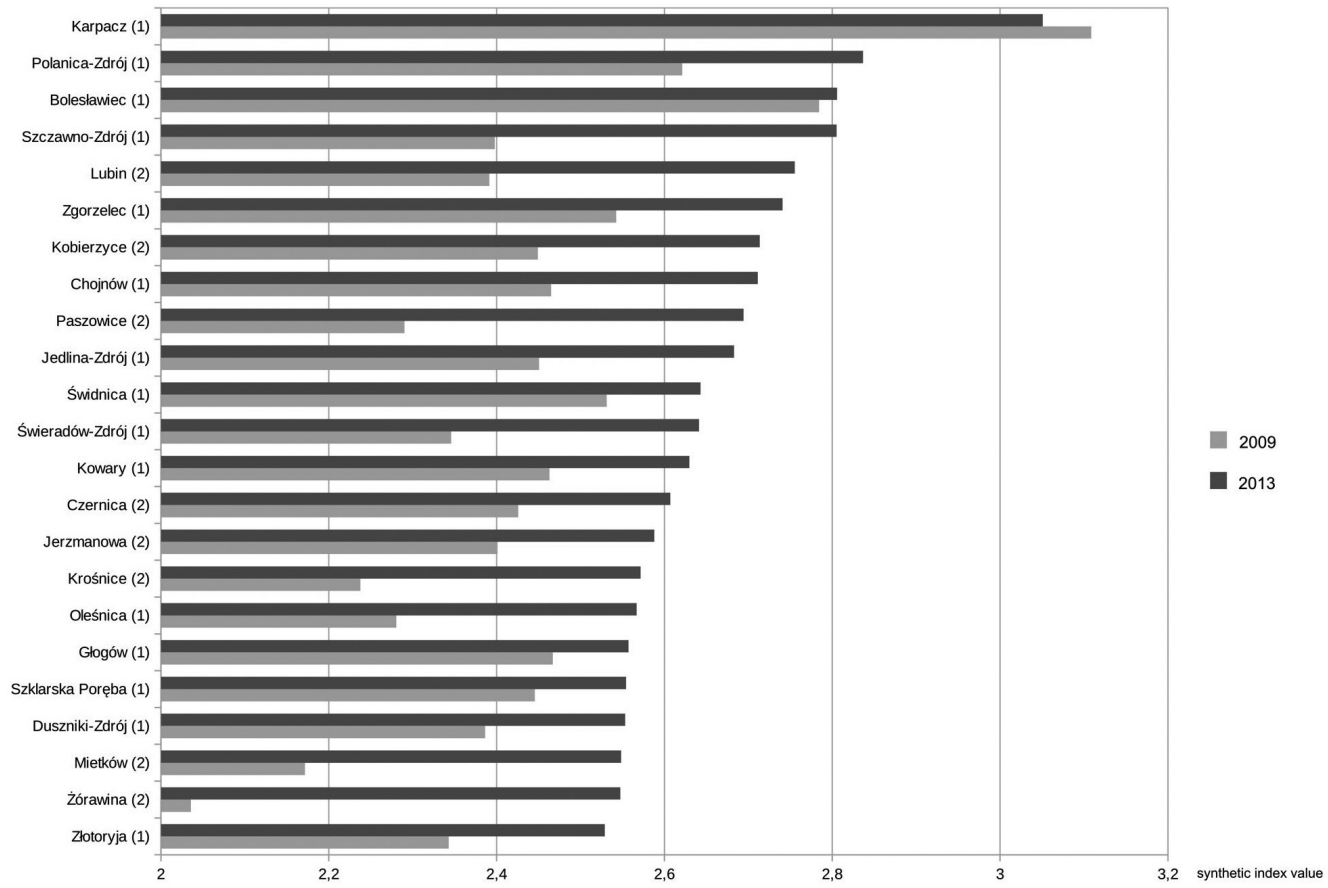

Fig. 7. Comparison of the state of spatial order in 2009 and 2013 in 23 communities best rated in 2009.

than 45 for the whole phenomenon, and more than 30 for only one aspect. Determining the number of key variables that really influence the composite index is the role of statistical techniques [44].

\section{Conclusions}

Assessing the level of community development in terms of spatial order is a complex task. Spatial order consists of several aspects, and each may be described by many variables. The main research difficulty was an incomplete database. Not all desirable data is available for each year, community and aspect. The selection of the appropriate characteristics has an impact on the results, and the rejection or acceptance of the characteristics may change the position of the community in the ranking. The cultural aspect data was insufficient, and for aesthetics there are no data. And without it, the assessment of the aesthetic aspect can be subjective, leading to different ratings and different interpretations of the phenomena occurring in community.

When selecting variables, a statistical verification was needed to assess the strength of the relationship and to exclude the overlap of ratings. The procedures allowed us to reduce selected variables to a common dimension that corresponds to spatial order and to all its aspects. These are the first published studies on the spatial order of southwestern communities of Poland. The results showed the diversity of rural and urban communities, especially in the functional aspect. It also showed that the level of spatial order and its individual elements of urban and rural communities are varied. The research helped identify the weaknesses in the specific aspects of the analyzed area and the highest-rated communities.

In the socio-economic and the functional aspects the majority of the communities obtained an average grade, and the lowest one in the field of environmental and cultural aspects. Probably the development of the communities is possible in the field of some of the studied aspects, especially in rural communities, e.g., development of the network system.

\section{Conflict of Interest}

The authors declare no conflict of interest.

\section{References}

1. SZMIDT B. rder of Space, $1^{\text {st }}$ ed.; P.I.W.: Warszawa, Poland 33, 1981 [In Polish].

2. GORZELAK G. Sketch of the dimensions ofthe spatialorder. In Społeczno-gospodarcze i przyrodnicze aspekty ładu przestrzennego; Ślęzak T., Zioło Z., Eds., Biuletyn KPZK PAN: Warszawa, Poland, 205, 55, 2003.

3. MIERZEJEWSKA L. Sustainable development as a category of spatial order. In Społeczno-gospodarcze i przyrodnicze aspekty ładu przestrzennego; Ślęzak T., Zioło Z., Eds., Biuletyn KPZK PAN: Warszawa, Poland, 205, 127, 2003

4. PARYSEK J.J.Spatial order as a conceptual and planning category. In Społeczno-gospodarcze i przyrodnicze aspekty ładu przestrzennego; Ślęzak T., Zioło Z., Eds., Biuletyn KPZK PAN: Warszawa, Poland, 205, 111, 2003.

5. GÓRCZYŃSKA M. Indicators for the Assessment of Spatial Organization and Spatial Order in City and in 
Urbanized Areas. In Wskaźniki zagospodarowania i ładu przestrzennego w gminach; Śleszyński P., Eds., Biuletyn KPZK PAN: Warszawa, Poland, 252, 87, 2013.

6. PODCIBORSKI T., JEDRZEJEWSKA K. Assessment of the status of the spatial order of built-up areas in villages in Warmia. Acta Scientiarium Polonorum, Administratio Locorum, 10 (4), 63, 2011.

7. AFFEK A. Proposition of Enviromental Indicators for Assessing of Spatial Organization and Spatial Order in Communes. In Wskaźniki zagospodarowania i ładu przestrzennego w gminach; Śleszyński P., Eds., Biuletyn KPZK PAN: Warszawa, Poland, 252, 51, 2013.

8. KORELSKI D. Parametrization of the state of development of rural communes in the małopolska region; Infrastructure and Ecology of Rural Areas, 5: Kraków, Poland, 35, 2010 [In Polish].

9. IUCN, UNEP and WWF. World Conservation Strategy, International Union for the Conservation of Nature. Gland, 1980.

10. BORYS T. Sustainable development indicators - effective form of detailing the new paradigm development. Vol. I What do we want to measure?. Zielona Planeta, 3 (90), 14, 2010.

11. BORYS T. Sustainable Development - How to recognize integrated order? Problemy Ekorozwoju - Problems of Sustainable Development, 6 (2), 75, 2011.

12. Towarzystwo Urbanistów Polskich. Available online: http://www.tup.org. pl/index.php? option=com_co ntent $\&$ view $=$ article $\& i d=478 \% 3$ Aopracowaniaplanistyczne-jako-narzdzia-ksztatowania-aduprzestrzennego\&Itemid $=203<=\mathrm{pl}$, (accessed on 20.12.2017)

13. PRUS A., ANTOLAK M., BARTOSZCZUK W., BARNECIAK A., JOPEK D., MACIEJEWSKA A., OLEŃSKI M., PIJANOWSKI J., SZUMIGAŁA P. Problems of shaping the spatial order. Wydawnictwo Uniwersytetu Rolniczego w Krakowie: Kraków, Poland, 2015.

14. POLSKI J. Ecological, social and economic aspects of the spatial order in the region. Research papers of Wrocław University of Economics 367, 240, 2014.

15. JAŁOWIECKI B., SZCZEPAŃSKI M.S. The city and space - the sociological perspective, $2^{\text {nd }}$ ed.; Wydawnictwo naukowe SCHOLAR: Warszawa, 373, 2006.

16. ZBIERSKA A., ZYDROŃ A., SZCZEPAŃSKI P. Indicatory evaluation of spatial order at the local level. Studia i prace wydziału nauk ekonomicznych i zarządzania, 40 (2), 189, 2015.

17. ŚLESZYŃSKI P. Development and spatial order indicators. Author's proposition. In Wskaźniki zagospodarowania i ładu przestrzennego w gminach; Śleszyński P., Eds., Biuletyn KPZK PAN: Warszawa, Poland, 252, 176, 2013.

18. KOZŁOWSKI L. Shaping spatial order as a research task for historical geography. Acta Universitatis Lodziensis Folia Geographica SocioOeconomica, 25, 5, 2016.

19. ZIOLO Z. The geographical space as a place of implementation of the idea ofthe spatial order. In Społeczno-gospodarcze i przyrodnicze aspekty ładu przestrzennego; Ślęzak T., Zioło Z., Eds., Biuletyn KPZK PAN: Warszawa, Poland, 205, 25, 2003.

20. ROSELAND M. Toward Sustainable Communities: Solutions for Citizens and Their Governments, $4^{\text {th }}$ ed.; New Society Publisher: Canada, 308, 2012.

21. PANEK T. Statistical methods of multidimensional comparative analysis. Szkoła Główna Handlowa w Warszawie: Warszawa, Poland, 19, 2009 [In Polish].
22. MYERS J.L., WELL A.D. Research Design and Statistical Analysis, $2^{\text {nd }}$ ed.; Mahwah, NJ: Lawrence Erlbaum, 2003.

23. BISHARA A.J., HITTNER J.B. Testing the significance of a correlation with nonnormal data: Comparison of Pearson, Spearman, transformation, and resampling approaches. Psychological Methods, 17 (3), 399, 2012.

24. WALESIAK $M$. Data normalization in multivariate data analysis. An overview and properties. Przegląd Statystyczny, LXI (4), 363, 2014.

25. JAROCKA $M$. The choice of a formula of the data normalization in the comparative analysis of multivariate objects. Economics and Management, 1 (2015), 113, 2015.

26. RUNGE J. Metody badań w geografii społecznoekonomicznej. Wydawnictwo Uniwersytetu Śląskiego: Katowice, Poland, 2007.

27. MIKOŁAJCZYK M., KRAJEWSKI P. Sewage system development in rural communities of the Jelenia Góra powiat. Infrastructure and Ecology of Rural Areas. II (1), 307, 2014

28. SZERWRAŃSKI S., KAZAK J., ŻMUDA R., WAWER R. Indicator-based assessment for soil resource management in the Wrocław Larger Urban Zone of Poland. Polish Journal of Environmental Studies, 26 (5), 2239, 2017.

29. ADAMSKA H., GOLINOWSKA M. Spatial diversity of social order of rural communes in south-western region of Polish. Journal of Agribusiness and Rural Development; 1 (31), 5, 2014.

30. ADAMSKA H. Spatial Diversity of Economic Governance of Rural Communes in Silesia Region. Roczniki Naukowe Stowarzyszenia Ekonomistów Rolnictwa i Agrobiznesu, XV (4), 16, 2013.

31. MRÓWKA J., MARKOWSKA M. Regional Strategy vs. Development Based on the Example of Lower Silesia Region. Prace Naukowe Wałbrzyskiej Wyższej Szkoły Zarządzania i Przedsiębiorczości, 33 (3), 191, 2015.

32. SOMPOLSKA-RZECHUŁA A. Water and Sanitary Infrastructure in Rural Areas in the Light of Economic Development at the Regional Level. Roczniki Naukowe Ekonomii Rolnictwa i Rozwoju Obszarów Wiejskich, 103 (2), 412016.

33. FLORIDI M., PAGNI S., FALORNI S., LUZZATI T. An exercise in composite indicators construction: Assessing the sustainability of Italian regions. Ecological Economics, 70 (8), 1440, 2011.

34. ÁCS Z.J., RAPPAI G., SZERB L. Index-building in a system of interdependent variables: The penalty for bottleneck. GMU School of Public Policy, Research Paper, 24 (2011), 1, 2011.

35. DECANCQ K., LUGO M. A. Weights in Multidimensional Indices of Wellbeing: An Overview. Econometric Reviews, 32 (1), 7, 2013.

36. JAROCKA M. Application selected methods of multidimensional comparative analysis to a hierarchy of Polish universities. Economics and Management 4 (2012), 27, 2012.

37. PAWLEWICZ K., PAWLEWICZ A. The Level of Spatial and Env ironmental Governance Rural Communities in Sustainable Development on the Example of Warmia and Mazurv Voivodship. Zeszyty Naukowe Wyższej Szkoły Bankowej w Poznaniu, 39 (2011), 171, 2011.

38. ZHOU P., ANG B.W., ZHOU D.Q. Weighting and aggregation in composite indicator construction: A multiplicative optimization approach. Social Indicators Research, 96 (1), 169, 2010. 
39. MAZZIOTA M., PARETO A. Methods for constructing composite indices: one for all or all for one? Rivista Italiana di Economia Demografia e Statistica, LXVII (2), 67, 2013.

40. MAZZIOTTA M., PARETO A. On a Generalized Noncompensatory Composite Index for Measuring Socioeconomic Phenomena. Social Indicators Research, 127 (3), 983, 2016.

41. KAZAK J., VAN HOOF J., SZEWRAŃSKI S. Challenges in the wind turbines location process in Central Europe - The use of spatial decision support systems. Renewable and Sustainable Energy Reviews 76 (2017), 425, 2017.
42. PARUOLO P., SAISANA M., SALTELLI A. Ratings and rankings: voodoo or science? Journal of the Royal Statistical Society, 176 (3), 609, 2012.

43. ZBIERSKA A., PRZYBYŁA K., ZBIERSKA J. Analysis of Sustainable Development Indicators in Spatial Economy at Local Level. Studia KPZK, 142 (2011), 157, 2011.

44. SINGH R.K., MURTY H.R., GUPTA S.K., DIKSHIT A.K. An overview of sustainability assessment methodologies. Ecological Indicators, 15 (1), 281, 2012.

45. ŚLESZYŃSKI P. Verification and testing of the development and spatial order indicators in communes. The report of the second stage works. PAN: Warszawa, Poland, 45, 2013. 